\title{
W KIERUNKU STUDENTYFIKACJI? ZAKWATEROWANIE STUDENCKIE W POLSKICH MIASTACH AKADEMICKICH
}

\author{
TOWARDS STUDENTIFICATION? STUDENTS' ACCOMMODATION \\ IN POLISH UNIVERSITY CITIES
}

\begin{abstract}
Student accommodation received recently particular attention of scholars. As evidenced in the United Kingdom - due to the massification of higher education - private accommodation markets started to expand in university cities. The paper aims to discuss these findings in Polish context taking into consideration data on students' populations and their use of halls of residence run by higher educational institutions (HEIs) in 18 major Polish university cities. While 10 cities experienced a growth of university students between 2004 and 2014, at the same time in 17 cities their number and proportion accommodated in halls of residence run by HEIs lowered. It is to say that majority of these cities most probably experienced an influx of students seeking private accommodation.
\end{abstract}

Keywords: student accommodation, university cities, students, halls of residence, studentification, PBSA

JEL classification: R31

* Uniwersytet Łódzki, Wydział Ekonomiczno-Socjologiczny, Instytut Gospodarki Przestrzennej, Katedra Gospodarki Regionalnej i Środowiska, jakub.zasina@uni.lodz.pl 


\section{Wprowadzenie}

Transformacja gospodarek z przemysłowych w kierunku usługowych, opartych na wiedzy, kreatywnych oraz inteligentnych skutkuje zwiększeniem popytu na wysokiej jakości kapitał ludzki, stanowiąc jeden z powodów upowszechnienia kształcenia na poziomie wyższym w skali ogólnoświatowej. W przypadku Polski tempo, skala i kierunki zmian zachodzących w szkolnictwie wyższym zasługują na szczególną uwagę, gdyż - jak zauważa M. Kwiek ${ }^{1}$ - pierwsze dekady transformacji gospodarczej były w niej okresem swoistej „eksplozji” systemu szkolnictwa wyższego. W konsekwencji miasta pełniące w sieci osadniczej rolę ośrodków akademickich doświadczyły lub nadal doświadczają napływu studentów. Chociaż system szkolnictwa wyższego w Polsce oraz jego przeobrażenia stanowiły przedmiot zainteresowania dość dużej grupy badaczy², wydaje się, że oddziaływanie studentów na gospodarkę i przestrzeń polskich miast akademickich pozostaje niewystarczająco poznanym zagadnieniem.

Jednym z ważniejszych aspektów obecności studentów w mieście akademickim jest ich aktywność na lokalnym rynku nieruchomości. Skala tej aktywności jest uwarunkowana wieloma czynnikami. Po pierwsze, atrakcyjność, wizerunek i ranga ośrodka akademickiego - w tym poziom jego umiędzynarodowienia - determinują liczbę studentów pochodzących spoza ośrodka akademickiego i jego bezpośredniego otoczenia ${ }^{3}$, a zatem poszukujących zakwaterowania w danym mieście na czas studiów. Po drugie, istotny czynnik stanowi polityka uczelni wyższych w obszarze zakwaterowania studenckiego. Uczelnie mogą prowadzić aktywną politykę, polegającą na zapewnianiu młodzieży akademickiej zakwaterowania $\mathrm{w}$ domach studenckich prowadzonych samodzielnie lub we współpracy z podmiotami prywatnymi. Przeciwieństwem jest sytuacja, w której uczelnie ograniczają aktywność na tym polu, niejako „wymuszając” na studentach samodzielne poszukiwanie zakwaterowania na rynku. Po trzecie, wielkość zasobów finansowych studentów (lub ich rodziców/opiekunów) warunkuje możliwość opuszczenia domu rodzinnego na czas studiów oraz znajduje przełożenie na standard i lokalizację zakwaterowania.

Zakwaterowanie studenckie w stosunkowo krótkim czasie stało się przedmiotem żywego zainteresowania badaczy, przede wszystkim brytyjskich. Wskazuje się, że gwałtowny rozwój rynków prywatnego zakwaterowania w tamtejszych ośrodkach akademickich stanowił jedną z konsekwencji umasowienia szkolnic-

${ }^{1}$ M. Kwiek, Prywatyzacja i deprywatyzacja: od ekspansji do implozji szkolnictwa wyższego w Polsce, „Praktyka Teoretyczna” 2015, nr 3, s. 120-145.

${ }^{2}$ Obszary badań omawia między innymi A. Bajerski, Przekształcenia struktury przestrzennej szkolnictwa wyższego w Polsce po 1989 r., Bogucki Wydawnictwo Naukowe, Poznań 2009.

${ }^{3}$ M.E. Sokołowicz, E.M. Boryczka, Tożsamość $i$ wizerunek dużego miasta wobec międzynarodowej mobilności osób dobrze wykształconych. Przykład Łodzi w oczach studentów łódzkich uczel$n i$, ,Zeszyty Naukowe Politechniki Poznańskiej. Architektura i Urbanistyka” 2011, nr 24, s. 1-12. 
twa wyższego. Ponieważ aktywność studentów na rynkach nieruchomości staje się coraz popularniejszym przedmiotem badań również w Polsce, za cel niniejszego artykułu przyjęto identyfikację wzorców korzystania przez studentów z zakwaterowania dostarczanego przez instytucje szkolnictwa wyższego. Analizie poddano liczbę studentów podejmujących naukę w 18 polskich ośrodkach akademickich oraz liczbę i odsetek studentów korzystających z uczelnianych akademików w latach 2004 i 2014. W oparciu o przegląd literatury przedmiotu w końcowej części artykułu wskazano potencjalne konsekwencje zidentyfikowanych zjawisk dla rynków zakwaterowania studenckiego.

\section{Emergencja rynków zakwaterowania studenckiego z perspektywy doświadczeń brytyjskich}

W obliczu umasowienia szkolnictwa wyższego i pojawiającego się problemu niewystarczającej podaży miejsc oferowanych w akademikach prowadzonych przez uczelnie studenci poszukują alternatywnego zakwaterowania ${ }^{4}$. Jak zauważają M. Munro i M. Livingston, efektywność, z jaką sektor prywatny potrafi odpowiedzieć na zwiększony popyt mieszkaniowy zgłaszany przez studentów, potrafi być „uderzająca”. W pierwszej kolejności popyt studentów na zakwaterowanie „pozauczelniane" prowadzi w mieście akademickim do przekształcania na potrzeby tej grupy najemców już istniejących zasobów mieszkaniowych, które uprzednio były zajmowane przez ,tradycyjne” gospodarstwa domowe. Zjawisko to ma swoje uzasadnienie w rachunku ekonomicznym, $w$ wielu bowiem przypadkach studenci współdzielący dom lub mieszkanie - tworzący niejako „studenckie gospodarstwa domowe" (ang. student households) - mogą wspólnie uiszczać przeciętnie wyższy czynsz w porównaniu z tradycyjnym gospodarstwem, nawet jeśli samodzielnie dysponują ograniczonymi środkami finansowymi. Dla właścicieli domów lub mieszkań zlokalizowanych w sąsiedztwach (osiedlach, ang. neighbourhoods) pożądanych przez studentów stanowi to bodziec do wyprowadzki i rozpoczęcia wynajmu posiadanej nieruchomości budynkowej lub lokalowej ${ }^{5}$.

W miastach brytyjskich - najpełniej udokumentowanych w literaturze przedmiotu - omawianym przekształceniom uległa przede wszystkim jednorodzinna zabudowa szeregowa. W niektórych miastach akademickich napływ studentów w poszczególne sąsiedztwa był tak intensywny, że zaczęto określać go mianem studentyfikacji (ang. studentification). Studentyfikacja prowadzi zatem do zmia-

${ }^{4}$ T. Nakazawa, Expanding the scope of studentification studies, „Geography Compass” 2017, nr 11, http://doi.org/10.1111/gec3.12300.

${ }^{5}$ M. Munro, M. Livingston, Student Impacts on Urban Neighbourhoods: Policy Approaches, Discourses and Dilemmas, „Urban Studies” 2012, vol. 49(8), s. 1679-1694, http://doi. org/10.1177/0042098011419237. 
ny kompozycji użytkowników danego sąsiedztwa: dotychczasowi mieszkańcy są wypierani przez nową grupę najemców - młodzież akademicką - co rodzi skojarzenia $\mathrm{z}$ gentryfikacją ${ }^{6}$. $\mathrm{Z}$ różnych powodów niektóre sąsiedztwa $\mathrm{w}$ miastach akademickich są bowiem dla studentów atrakcyjniejsze od pozostałych (bliskość infrastruktury dydaktycznej, oferta połączeń komunikacją miejską, studencka atmosfera itp. $)^{7}$.

Pierwszą odpowiedź na zaspokajanie zwiększonego popytu na zakwaterowanie studenckie stanowią działania podejmowane przez liczne grono właścicieli domów lub mieszkań. Z czasem na rynku pojawia się grupa właścicieli dysponujących większym ,portfolio" nieruchomości wynajmowanych studentom. Warto bowiem zauważyć, że adaptacja domu lub mieszkania do potrzeb młodzieży akademickiej nie wymaga zazwyczaj ponoszenia wysokich nakładów inwestycyjnych, umożliwia natomiast właścicielom zwiększenie korzyści czerpanych z tytułu naj$\mathrm{mu}^{8}$. Ponadto studenci cechują się relatywnie wysoką elastycznością w zakresie adaptacji do oferowanego zakwaterowania: potrafią dzielić między sobą zarówno małe mieszkania, jak i całe domy. Rynek zakwaterowania studenckiego w dłuższym horyzoncie czasowym podlega istotnemu przeobrażeniu za sprawą zainteresowania nim zgłaszanego przez dużych inwestorów, niejednokrotnie operujących w skali ogólnokrajowej.

Brak lub niewystarczająca liczba inwestycji w uczelniane domy studenckie, postępujące umiędzynarodowienie szkolnictwa wyższego, a także rosnące oczekiwania studentów wobec jakości zajmowanego zakwaterowania i jego lokalizacji w obrębie miasta sprzyjają uruchamianiu inwestycji określanych mianem PBSA, będących celowo wznoszonymi obiektami zakwaterowania studenckiego (ang. Purpose Built Student Accommodation) przez podmioty prywatne 9 . Przykłady brytyjskie wskazują, że obiekty PBSA różnią się między sobą oferowanym standardem. Warto mieć jednak na uwadze, że najbardziej luksusowe obiekty PBSA w Wielkiej Brytanii oferują studentom dostęp do szeregu wygód (ang. facilities), takich jak pokoje do wspólnego spędzania wolnego czasu, klubokawiarnie, siłownie, pralnie itp. Ich zaletą jest często centralna lokalizacja w strukturze przestrzennej miasta, za sprawą której studenci mogą korzystać z oferty życia kulturalnego i nocnego. Obiekty typu PBSA stanowią zatem konkurencyjną ofertę na rynku zakwaterowania studenckiego, zwiększenie podaży oferowanych w nich miesz-

${ }^{6}$ D.P Smith, "Studentification ication”: the gentrification factory?, [w:] R. Atkinson, G. Bridge (eds.), Gentrification in a global context: the new urban colonialism, Routledge, London 2005.

${ }^{7}$ J. Allinson, Over-Educated, Over-Exuberant and Over Here? The Impact of Students on Cities, „Planning Practice and Research” 2006, vol. 21(1), s. 79-94, http://doi. org/10.1080/02697450600901541.

${ }^{8}$ J. Rugg, D. Rhodes, A. Jones, Studying a Niche Market: UK Students and the Private Rented Sector, ,Housing Studies” 2002, vol. 17(2), s. 289-303, http://doi.org/10.1080/02673030220123234.

${ }^{9}$ P. Hubbard, Geographies of Studentification and Purpose-Built Student Accommodation: Leading Separate Lives?, „Environment and Planning A” 2009, vol. 41(8), s. 1903-1923, http://doi. org/10.1068/a4149. 
kań może zaś prowadzić do tzw. destudentyfikacji (ang. destudentification), czyli odpływu studentów z sąsiedztw, w których wcześniej obserwowano ich koncentrację ${ }^{10}$.

Wznoszeniu obiektów typu PBSA niejednokrotnie sprzyjają władze miast akademickich oraz uczelni, które upatrują w tym działaniu szansę na rozwiązanie problemu niewystarczającej podaży zakwaterowania studenckiego (np. w Irlandii ${ }^{11}$ ), na stworzenie oferty mieszkaniowej przekładającej się na wyższą atrakcyjność miasta jako miejsca podejmowania studiów, na złagodzenie napięć społecznych wynikających z intensyfikacji życia studenckiego w tradycyjnych sąsiedztwach mieszkaniowych bądź na ożywienie zdegradowanych obszarów miast przez ulokowanie obiektów PBSA na terenach typu brownfields (np. pofabrycznych lub poportowych $)^{12}$. W ostatnim przypadku otwarte pozostaje pytanie o to, w jakim stopniu inwestycje typu PBSA mogą wpisać się w szerzej rozumianą rewitalizację zdegradowanych obszarów miast, jako że niejednokrotnie polegają one na adaptacji obiektów stanowiących lokalne zasoby dziedzictwa kulturowego, w tym dziedzictwa poprzemysłowego. Za sprawą inwestycji PBSA zdegradowany obszar miasta zyskuje ponadto pokaźną liczbę nowych użytkowników - studentów - których obecność może prowadzić do ożywienia gospodarczego okolicy. Z drugiej strony, według M. Holtona i M. Rileya, obiekty PBSA budzą uzasadnione skojarzenia $\mathrm{z}$ tzw. osiedlami grodzonymi (ang. gated communities) ${ }^{13}$.

\section{Materiały i metodyka analizy}

Do przeprowadzenia analizy zmian zachodzących w liczbie studentów oraz w korzystaniu przez nich z domów studenckich posłużono się danymi udostępnionymi przez Urząd Statystyczny w Gdańsku dla 18 miast akademickich w Polsce ${ }^{14}$ :

${ }^{10}$ C. Kinton, D.P. Smith, J. Harrison, De-studentification: emptying housing and neighbourhoods of student populations, „Environment and Planning A” 2016, vol. 48(8), s. 1617-1635, http:// doi.org/10.1177/0308518X16642446.

${ }^{11}$ T. Kenna, Studentification in Ireland? Analysing the impacts of students and student accommodation on Cork City, „Irish Geography” 2011, vol. 44(2-3), s. 191-213, http://doi.org/10.10 80/00750778.2011.618073.

${ }^{12}$ P. Hubbard, op. cit.,

${ }^{13}$ M. Holton, M. Riley, Student Geographies: Exploring the Diverse Geographies of Students and Higher Education, „Geography Compass” 2013, vol. 7(1), s. 61-74, http://doi.org/10.1111/ gec3.12013.

${ }^{14} \mathrm{~W}$ analizach przestrzennych dotyczących systemu szkolnictwa wyższego można stosować kategorię „zespołu miejskiego” w przypadku, kiedy w ramach konurbacji wyróżnić można kilka miast pełniących funkcję akademicką (np. Bajerski, op. cit.,). Przykładowo, wiele miast Górnego Śląska oraz Gdańsk, Gdynia i Sopot, tworzące Trójmiasto, stanowią siedziby uczelni wyższych lub ich filii. Ponieważ dla obszaru Górnego Śląska dysponowano danymi wyłącznie dla Katowic i Gli- 
Białegostoku, Bydgoszczy, Częstochowy, Gdańska, Gliwic, Katowic, Kielc, Krakowa, Lublina, Łodzi, Olsztyna, Poznania, Rzeszowa, Szczecina, Torunia, Warszawy, Wrocławia i Zielonej Góry ${ }^{15}$. W formie opisu tabelarycznego oraz wykresu rozrzutu zaprezentowano dane dotyczące liczby studentów stacjonarnych, kształcących się w poszczególnych ośrodkach akademickich, a także liczby i odsetka studentów stacjonarnych zakwaterowanych w domach studenckich prowadzonych przez uczelnie wyższe. Dane pozyskano za lata 2004 i 2014, wyznaczające pierwszą dekadę członkostwa Polski w Unii Europejskiej, w trakcie której obserwowano intensywną rozbudowę infrastruktury akademickiej. Warto dodać, że pozyskane dane dotyczyły wyłącznie studentów kształcących się w trybie stacjonarnym (na uczelniach publicznych i prywatnych) - ze względu na ich częstszą potrzebę zakwaterowania w mieście akademickim w porównaniu ze studentami studiów niestacjonarnych.

wic, a w przypadku Trójmiasta wyłącznie dla Gdańska, w omawianej analizie miasta te potraktowano rozdzielnie i nie zastosowano w ich przypadku kategorii „zespołu miejskiego”.

${ }^{15} \mathrm{Z}$ uwagi na metodykę gromadzenia danych o wskazanym zakresie przedmiotowym liczba studentów przypisana danemu miastu akademickiemu wynika z położenia siedziby uczelni wyższej w danym mieście, a nie z faktycznego miejsca zamieszkiwania studentów. 
W kierunku studentyfikacji? Zakwaterowanie studenckie...

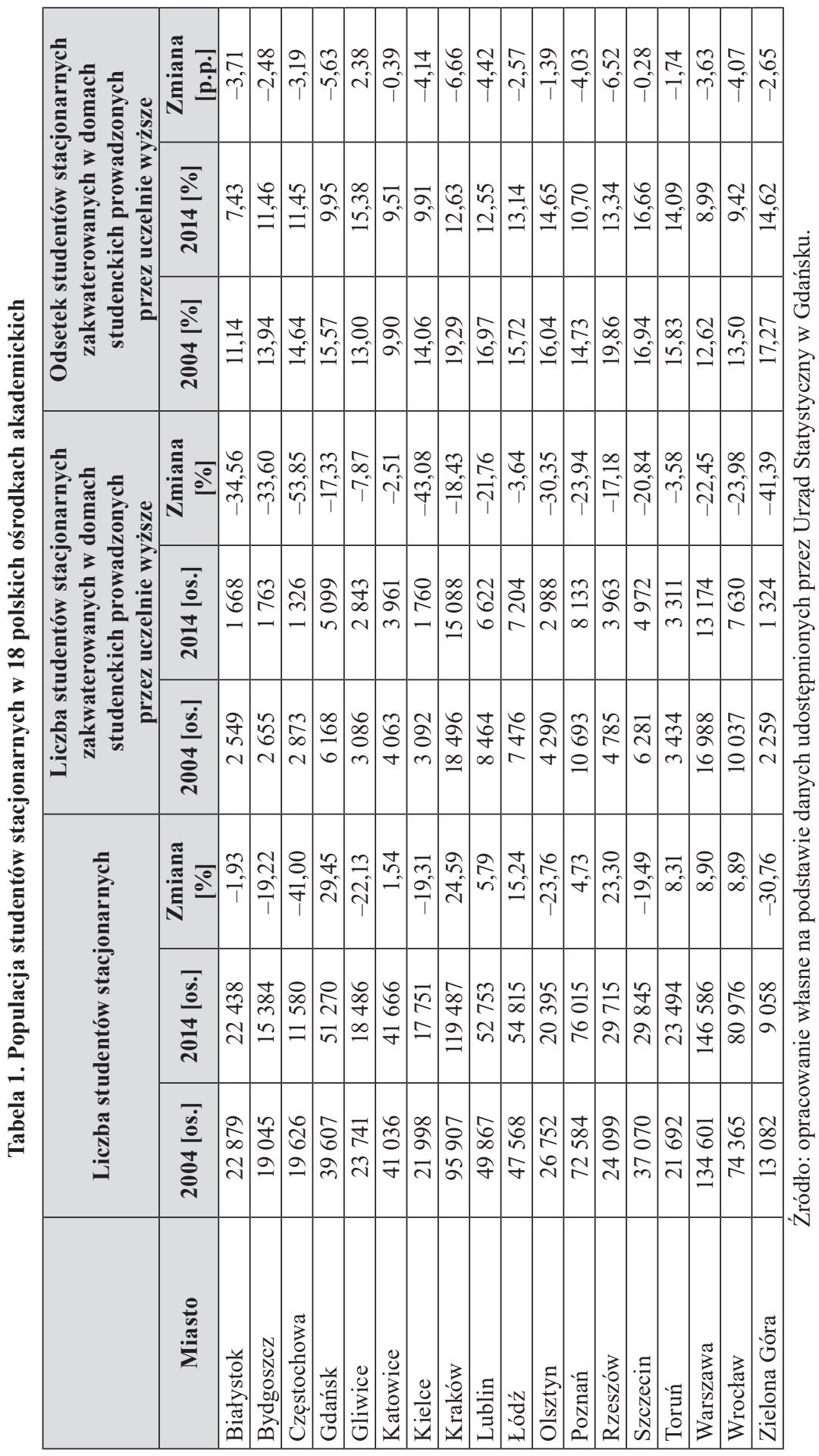




\section{Wyniki analizy}

W niniejszej części omówiono zmiany, które zaszły w liczbie osób studiujących w trybie stacjonarnym w 18 miastach akademickich w Polsce w latach 2004 i 2014. Warto zauważyć, że miasta te istotnie różniły się między sobą w zakresie liczby studentów stacjonarnych zarówno w roku 2004, jak i dekadę później. Mając na uwadze tę statystykę, największym ośrodkiem w roku 2004 była Warszawa, w której studia stacjonarne podejmowało 134601 osób, z kolei najmniejsza liczba studentów była wówczas domeną Zielonej Góry - 13082 osoby. Chociaż żaden z ośrodków akademickich - poza Warszawą - nie liczył w roku 2004 więcej niż 100000 studentów stacjonarnych, trzy ośrodki cechowały się ich liczbą większą od 50 000. Były to Kraków (95 907), Wrocław (74 365) oraz Poznań (72 584).

Analizowane miasta akademickie różniły się pod względem skali i kierunku zmian w liczbie studentów stacjonarnych między rokiem 2004 a 2014. Większość omawianych ośrodków - dziesięć - odnotowało w tym okresie wzrost liczby studentów, z kolei w pozostałych ośmiu ośrodkach nastąpiło jej zmniejszenie. Największy wzrost liczby studentów - wynoszący powyżej 20\% - dotyczył trzech ośrodków, tj. Gdańska (29,45\%), Krakowa (24,59\%) oraz Rzeszowa (23,3\%). Relatywnie wysoki wzrost liczby studentów był także domeną Łodzi (15,24\%). Wśród ośrodków, które zwiększyły liczbę studentów wskazać należy ponadto Warszawę $(8,9 \%)$, Wrocław $(8,89 \%)$, Toruń $(8,31 \%)$, Lublin (5,79\%), Poznań (4,73\%) i Katowice $(1,54 \%)$. Interesująca jest obserwacja, że wysokiemu wzrostowi w czterech miastach akademickich oraz umiarkowanemu wzrostowi w kolejnych sześciu towarzyszył spadek liczby studentów aż w ośmiu analizowanych ośrodkach. Choć w przypadku jednego z tych miast - Białegostoku - spadek liczby studentów należy uznać za niewielki (-1,93\%), w dwóch ośrodkach ich ubytek był wyjątkowo duży - w Zielonej Górze (-30,76\%) oraz w Częstochowie (-41\%).

W ciągu dekady ,ranga" miast akademickich określana liczbą studentów stacjonarnych uległa zatem zmianie, przy czym pozycje wzmocniły przede wszystkim największe ośrodki akademickie oraz Gdańsk i Rzeszów. Warszawa utrzymała pierwszą pozycję (146 586), chociaż liczba studentów stacjonarnych podejmujących naukę w Krakowie (119 487) zbliżyła się do wyniku stołecznego. Do grona miast akademickich kształcących ponad 50000 studentów stacjonarnych - Wrocławia (80 976) i Poznania (76 015) - dołączyły również Łódź (54 815), Lublin (52 753) oraz Gdańsk (51 270). Podobnie jak przed dekadą, miastem o najmniejszej liczbie studentów stacjonarnych okazała się Zielona Góra (9058), która w roku 2014 była również jedynym miastem z próby z liczbą studentów wynoszącą poniżej 10000 .

Przy założeniu, że model zakwaterowania studenckiego nie ulega zmianie wraz ze zmianą liczby studentów, należałoby oczekiwać wzrostu liczby żaków zakwaterowanych $\mathrm{w}$ domach studenckich prowadzonych przez uczelnie $\mathrm{w}$ tych ośrodkach, które zwiększały liczbę studentów, a także zmniejszenia liczby stu- 
dentów zakwaterowanych w uczelnianych akademikach w przypadku tych miast, które doświadczyły ubytku młodzieży akademickiej. Analiza danych pozwala jednak stwierdzić, że we wszystkich miastach objętych analizą zmalała liczba studentów korzystających z zakwaterowania oferowanego przez uczelnie, a w zdecydowanej większości miast (17) zmniejszeniu uległ również ich odsetek w liczbie studentów ogółem.

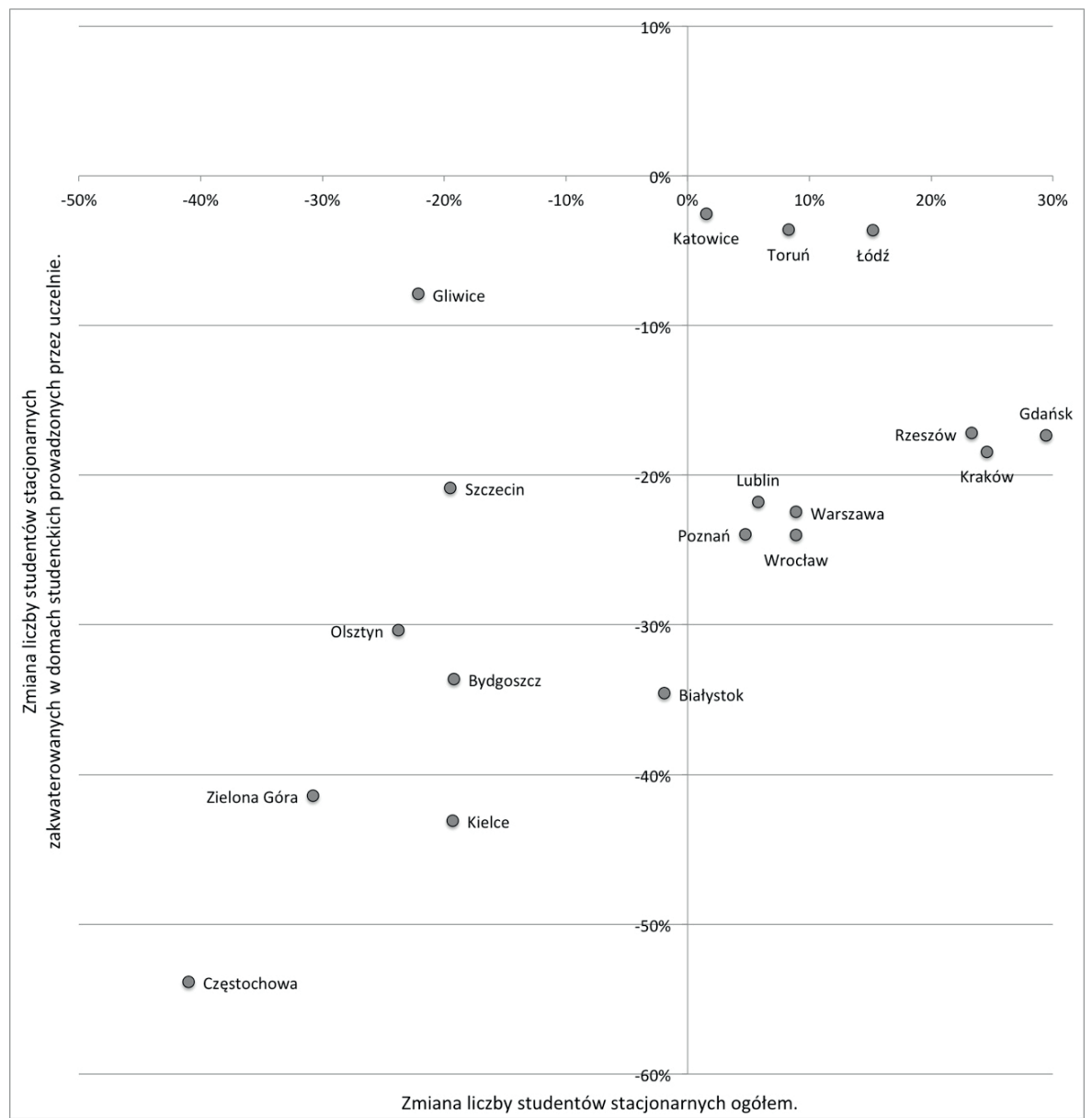

Rysunek 1. Zależność między zmianą liczby studentów stacjonarnych ogółem a zmianą liczby studentów stacjonarnych zakwaterowanych $w$ domach studenckich prowadzonych przez uczelnie wyższe w 18 miastach akademickich w Polsce między rokiem 2004 i 2014

Źródło: opracowanie własne na podstawie danych udostępnionych przez Urząd Statystyczny w Gdańsku.

W każdym z dziesięciu miast, które doświadczyły zwiększenia liczby studentów stacjonarnych, odnotowano jednocześnie ubytek w liczbie studentów sta- 
cjonarnych korzystających z zakwaterowania oferowanego przez uczelnie. Miasta te można podzielić na trzy grupy (zob. rys. 1). Pierwszą z nich stanowią Katowice, Łódź oraz Toruń, które zwiększając liczbę studentów, odnotowały zmniejszenie liczby studentów zakwaterowanych w uczelnianych domach studenckich na poziomie nie większym niż 4\%. Drugą grupę tworzą z kolei Gdańsk, Kraków oraz Rzeszów, a zatem ośrodki, które w największym stopniu zwiększyły liczbę studentów w dekadzie 2004-2014. W ich przypadku liczba studentów zakwaterowanych w domach studenckich prowadzonych przez uczelnie zmalała o około $18 \%$. Wreszcie w trzeciej grupie miast zwiększających liczbę studentów - będących zarazem dużymi ośrodkami akademickimi, tj. w Lublinie, Poznaniu, Warszawie i we Wrocławiu - odnotowano najwyższe spadki w liczbie studentów korzystających z zakwaterowania oferowanego przez uczelnie - wyniosły one od 21,76 do $23,98 \%$.

W kolejnych ośmiu miastach - o malejącej liczbie studentów - również obserwowano zmniejszającą się liczbę studentów zakwaterowanych w domach studenckich prowadzonych przez uczelnie. W większości przypadków spadek liczby studentów korzystających z uczelnianych akademików przewyższał spadek liczby studentów ogółem (Białystok, Bydgoszcz, Częstochowa, Kielce, Olsztyn i Zielona Góra), w jednym zaś kierunek był odwrotny (Gliwice). Tylko w przypadku Szczecina obie wartości zmalały niemal równomiernie.

Zmiany te znalazły odzwierciedlenie w odsetku studentów stacjonarnych korzystających z zakwaterowania oferowanego przez uczelnie. We wszystkich miastach, dla których przeprowadzono analizę - z wyjątkiem Gliwic - odnotowano zmniejszenie wartości omawianego odsetka. Jej spadek wyniósł w ciągu dekady 2004-2014 od 0,28 punktu procentowego w Szczecinie do 6,66 punktu procentowego w przypadku Krakowa. O ile w roku 2004 odsetek studentów korzystających z zakwaterowania oferowanego przez uczelnie niższy niż $10 \%$ był domeną tylko jednego miasta - Katowic, o tyle dekadę później liczba takich miast zwiększyła się do sześciu (Białystok, Gdańsk, Katowice, Kielce, Warszawa, Wrocław). Lokalne rynki nieruchomości we wskazanych miastach mogły zatem uzyskać nowych, młodych najemców w postaci młodzieży akademickiej. Potwierdzenie tego spostrzeżenia wymaga jednak przeprowadzenia pogłębionych badań pierwotnych w poszczególnych ośrodkach ze względu na ograniczenia zakresu danych gromadzonych w statystyce publicznej.

\section{Dyskusja}

Bez względu na to, czy liczba studentów w danym mieście akademickim malała, czy rosła, we wszystkich uwzględnionych w analizie miastach zmniejszeniu uległa liczba studentów korzystających z zakwaterowania oferowanego przez uczelnie, 
a w zdecydowanej większości (poza Gliwicami) zmalał również ich odsetek. Wyjaśnienie źródeł tego zjawiska jest utrudnione ze względu na brak szczegółowych danych o miejscu faktycznego zamieszkiwania studentów. Można jednak przyjąć dwa potencjalne źródła zidentyfikowanego zjawiska. Po pierwsze, uczelnie mogły odstąpić od zwiększania liczby miejsc oferowanych studentom w domach studenckich. Wydaje się, że choć w dekadzie 2004-2014 uczelnie wiele inwestowały w rozbudowę własnej infrastruktury, inwestycje te dotyczyły przede wszystkim obiektów służących działalności dydaktycznej i naukowej. Nie oznacza to jednak, że uczelnie całkowicie wycofały się z inwestowania w domy studenckie, zmniejszenie liczby zakwaterowanych w nich studentów mogło bowiem wynikać także $\mathrm{z}$ przeprowadzanych remontów w celu podnoszenia standardu zakwaterowania, między innymi przez zmniejszanie liczby miejsc (łóżek) przypisanych do jednego pokoju/mieszkania. Po drugie, zmianom mogły ulec gusta i preferencje studentów, którzy chcąc prowadzić bardziej miejski styl życia lub dysponować zakwaterowaniem o wyższym standardzie, mogli zaczać znajdować zakwaterowanie poza kampusami akademickimi, co sugerują doświadczenia brytyjskie ${ }^{16}$.

Ze względu na specyfikę struktury przestrzennej miast brytyjskich i spopularyzowanego w nich modelu zamieszkiwania w zabudowie jednorodzinnej, stosunkowo trudno przenieść zidentyfikowane tam wzorce studentyfikacji bezpośrednio na realia polskie. Niemniej wyniki dotychczasowych badań sugerują, że model zakwaterowania studenckiego w rodzimych ośrodkach akademickich przypomina do pewnego stopnia zjawisko zidentyfikowane w Hiszpanii i określane mianem „studentyfikacji wertykalnej” (ang. vertical studentification) ${ }^{17}$. Rozumie się przez nią użytkowanie przez studentów mieszkań w zabudowie wielorodzinnej. Innymi słowy, intensyfikacja zakwaterowania studenckiego w tym wariancie następuje nie tyle na obszarze „horyzontalnych” osiedli domów jednorodzinnych, lecz w „wertykalnej” zabudowie kamienicznej. Wydaje się, że „studentyfikacja wertykalna" trafniej odnosi się do procesów, które zaszły w polskich miastach akademickich w ostatnich latach. Jak bowiem wynika z badań przeprowadzonych w Krakowie, Łodzi, Poznaniu oraz Trójmieście, studenci wynajmujący zakwaterowanie na rynku relatywnie rzadko zamieszkują w domach jednorodzinnych, na ogół użytkując mieszkania w zabudowie wielorodzinnej: najczęściej blokowej, rzadziej kamienicznej ${ }^{18}$.

${ }^{16}$ P. Hubbard, op. cit., s. 1903-1923.

${ }^{17}$ M. Garmendia, J.M. Coronado, J.M. Ureña, University Students Sharing Flats: When Studentification Becomes Vertical, „Urban Studies” 2012, vol. 49(12), s. 2651-2668, http://doi. org/10.1177/0042098011428176.

${ }^{18}$ M. Grabkowska, J. Frankowski, "Close to the city centre, close to the university". Are there symptoms of studentification in Gdańsk, Poland?, „Bulletin of Geography. Socio-Economic Series” 2016, vol. 32, s. 73-83, http://doi.org/10.1515/bog-2016-0016; J. Jakóbczyk-Gryszkiewicz, S. Marcińczak, A. Wolaniuk, Gentrification processes in the city, [w:] T. Marszał (red.), Society and space in contemporary Poland in Eódź University Geographical Research, Wydawnictwo Uniwersytetu Łódzkiego, Łódź 2014; J. Kotus, M. Rzeszewski, A. Bajerski, Przyjezdni w strukturze miasta - mia- 


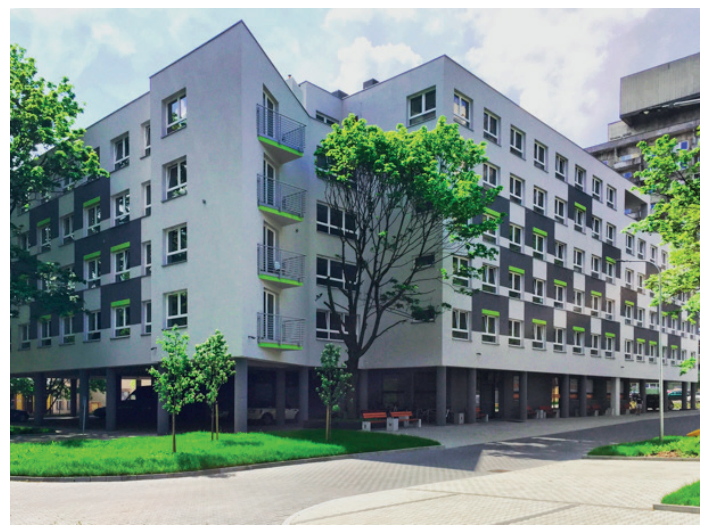

Fotografia 1. Inwestycja typu PBSA w Lodzi: akademik Salsa Źródło: fotografie autora, 2016.

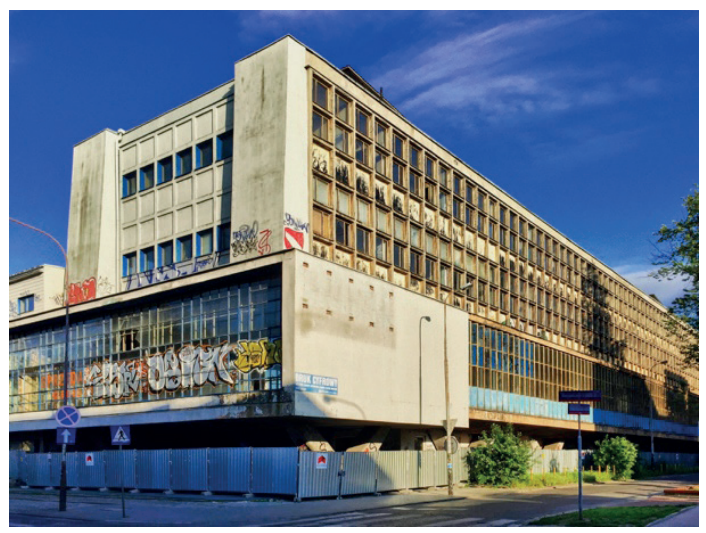

Fotografia 2. Inwestycje typu PBSA w Lodzi: gmach Lódzkiej Drukarni Dziełowej w trakcie przebudowy na hotel studencki Basecamp

Źródło: fotografia autora, 2016.

Jednym z przejawów rosnącej atrakcyjności zakwaterowania studenckiego jako segmentu rynku nieruchomości w polskich miastach akademickich jest między innymi uruchamianie pierwszych inwestycji typu PBSA. W największych ośrodkach poszczególni inwestorzy zapowiadają lub rozpoczęli projekty określane jako ,prywatne akademiki” lub „hotele studenckie”. Przykładem jest Łódź, w której w roku 2015 otwarto nowo wybudowany prywatny akademik Salsa (fot. 1), oferujący 267 pokoi, a zaś w roku 2017 zostanie ukończony hotel studencki Ba-

sto wobec przyjezdnych: studenci i turyści w mieście w kontekście koncepcji city users, Bogucki Wydawnictwo Naukowe, Poznań 2016; M. Murzyn-Kupisz, M. Szmytkowska, Studentification in The Post-Socialist Context: The Case of Cracow and The Tri-City (Gdansk, Gdynia and Sopot), „Geografie” 2015, vol. 120(2), s. 188-209. 
secamp dysponujący około 500 pokojami w wyniku przebudowy gmachu dawnej Łódzkiej Drukarni Dziełowej (fot. 2). Lokalizację obu obiektów należy określić jako śródmiejską, pozostającą się w bliskim (lub bezpośrednim) sąsiedztwie infrastruktury dydaktycznej łódzkich uczelni. Przewidziano w nich dodatkowe „wygody” dla studentów-najemców: „Salsę” wyposażono w siłownię, z kolei „Basecamp" zostanie uzupełniony między innymi o stołówkę, klub muzyczny i punkty usługowe w parterze.

Wskazane inwestycje typu PBSA były/są realizowane w Łodzi, w której odsetek studentów zakwaterowanych w akademikach prowadzonych przez uczelnie pozostaje relatywnie wysoki $(13,14 \%)$ na tle innych miast. Podobnych inwestycji można zatem oczekiwać w miastach doświadczających zwiększania lub stabilizacji liczby studentów oraz cechujących się niższą wartością omawianego odsetka. Wydaje się jednak, że odbiorcami obiektów typu PBSA w Polsce, za sprawą stosunkowo wysokich cen oferowanych w nich pokoi/łóżek, będą w pierwszej kolejności studenci dysponujący większymi środkami finansowymi, w tym obcokrajowcy. $\mathrm{Ci}$ ostatni przeznaczają bowiem przeciętnie więcej pieniędzy na zakwaterowanie w porównaniu ze studentami polskimi ${ }^{19}$, a także mogą cechować się wyższymi oczekiwaniami w zakresie standardu zamieszkania lub chęcią zamieszkania w towarzystwie innych zagranicznych studentów w nowym, nieznanym miejscu ${ }^{20}$.

W przeciwieństwie do miast zwiększających liczbę studentów, miasta akademickie, które w dekadzie 2004-2014 najprędzej ich traciły, mogą w najbliższych latach stanąć przed zupełnie innym wyzwaniem: koniecznością znalezienia nowych użytkowników dla mieszkań obecnie zajmowanych przez młodzież akademicką, za sprawą malejącego popytu po stronie kurczącej się liczby studentów. Zadanie to może okazać się utrudnione ze względu na występujące tendencje depopulacyjne w części z nich.

\section{Podsumowanie i wnioski}

W artykule podjęto temat przeobrażeń zachodzących na rynkach nieruchomości za sprawą zmian liczby studentów oraz zmian w korzystaniu przez nich z domów studenckich prowadzonych przez uczelnie. W drodze analizy danych statystycznych za lata 2004 i 2014 dla 18 polskich miast akademickich stwierdzono, że choć doświadczały one wzrostu (10 miast) lub spadku (8 miast) liczby studentów stacjo-

${ }^{19}$ M. Lipowski, Student as consumer. Benefits of being academic city, referat zaprezentowany podczas konferencji „Human Capital without Borders Knowledge and Learning for Quality of Life", Portorož 2014.

${ }^{20}$ F.L. Collins, International students as urban agents: International education and urban transformation in Auckland, New Zealand, „Geoforum” 2010, vol. 41(6), s. 940-950, http://doi. org/10.1016/j.geoforum.2010.06.009. 
narnych, to we wszystkich zmniejszeniu uległa liczba studentów stacjonarnych korzystających z zakwaterowania oferowanego przez uczelnie wyższe. W rezultacie w 17 miastach nastąpiło zmniejszenie odsetka studentów stacjonarnych korzystających z akademików prowadzonych przez uczelnie. Dla lokalnych rynków nieruchomości mogło to skutkować zwiększeniem popytu na zakwaterowanie ze strony młodzieży akademickiej.

Doświadczenia brytyjskie wskazują, że po etapie zaspokajania popytu na zakwaterowanie studenckie $w$ drodze przekształcania już istniejących mieszkań lub domów do potrzeb studentów, rynki nieruchomości w ośrodkach akademickich są uzupełniane o inwestycje typu PBSA, czyli obiekty zakwaterowania studenckiego wznoszone przez podmioty prywatne. Realizacja takiego scenariusza w rodzimych ośrodkach oznaczałaby wytworzenie specyficznego dla Polski wzorca studentyfikacji. Mianowicie po początkowym napływie studentów do mieszkań w zabudowie blokowej, na ogół w peryferyjnie zlokalizowanych dużych osiedlach mieszkaniowych z okresu powojennego, nastąpiłby etap wznoszenia inwestycji typu PBSA, przynajmniej częściowo w dzielnicach śródmiejskich. Jednak skala inwestycji tego typu jest obecnie trudna do oszacowania.

Chociaż rola studentów jako użytkowników miast może być przewartościowywana $^{21}$, wydaje się, że w warunkach polskich studenci mogą stanowić istotną grupę najemców na rynkach nieruchomości mieszkaniowych, także z uwagi na postępującą depopulację wielu ośrodków miejskich. Precyzyjne określenie znaczenia studentów dla przeobrażeń rynków nieruchomości w rodzimych ośrodkach akademickich wymaga jednak przeprowadzenia pogłębionych analiz ilościowych i jakościowych nad mobilnością przestrzenną studentów oraz ich stylami życia w poszczególnych ośrodkach akademickich, co wykracza poza zakres niniejszego artykułu. Istotnymi uwarunkowaniami popytu na zakwaterowanie studenckie w polskich miastach będą ponadto szersze (regionalne, krajowe) tendencje demograficzne oraz popularność edukacji na poziomie wyższym.

\section{Bibliografia}

Allinson J., Over-Educated, Over-Exuberant and Over Here? The Impact of Students on Cities, „Planning Practice and Research"2006, vol.21(1), s. 79-94, http://doi.org/10.1080/02697450600901541.

Bajerski A., Przekształcenia struktury przestrzennej szkolnictwa wyższego w Polsce po 1989 r., Bogucki Wydawnictwo Naukowe, Poznań 2009.

Collins F.L., International students as urban agents: International education and urban transformation in Auckland, New Zealand, „Geoforum” 2010, vol. 41(6), s. 940-950, http://doi. org/10.1016/j.geoforum.2010.06.009.

Garmendia M., Coronado J.M., Ureña J.M., University Students Sharing Flats: When Studentification Becomes Vertical, „Urban Studies” 2012, vol. 49(12), s. 2651-2668, http://doi. org/10.1177/0042098011428176.

${ }^{21}$ M. Nowak, Mieszkaniec a użytkownik zewnętrzny - perspektywa krytyczna, ,Rozwój Regionalny i Polityka Regionalna” 2015, nr 31, s. 7-16. 
Grabkowska M., Frankowski J., ,, Close to the city centre, close to the university”. Are there symptoms of studentification in Gdańsk, Poland?, „Bulletin of Geography. Socio-Economic Series” 2016, vol. 32, s. 73-83, http://doi.org/10.1515/bog-2016-0016.

Holton M., Riley M., Student Geographies: Exploring the Diverse Geographies of Students and Higher Education, „Geography Compass” 2013, vol. 7(1), s. 61-74, http://doi.org/10.1111/ gec3.12013.

Hubbard P., Geographies of Studentification and Purpose-Built Student Accommodation: Leading Separate Lives?, „Environment and Planning A” 2009, vol. 41(8), s. 1903-1923, http://doi. org/10.1068/a4149.

Jakóbczyk-Gryszkiewicz J., Marcińczak S., Wolaniuk A., Gentrification processes in the city, [w:] T. Marszał (red.), Society and space in contemporary Poland in Łódź University Geographical Research, Wydawnictwo Uniwersytetu Łódzkiego, Łódź 2014.

Kenna T., Studentification in Ireland? Analysing the impacts of students and student accommodation on Cork City, „Irish Geography” 2011, vol. 44(2-3), s. 191-213, http://doi.org/10.1080/0 0750778.2011.618073.

Kinton C., Smith D.P., Harrison J., De-studentification: emptying housing and neighbourhoods of student populations, „Environment and Planning A” 2016, vol. 48(8), s. 1617-1635, http:// doi.org/10.1177/0308518X16642446.

Kotus J., Rzeszewski M., Bajerski A., Przyjezdni w strukturze miasta-miasto wobec przyjezdnych: studenci i turyści w mieście w kontekście koncepcji city users, Bogucki Wydawnictwo Naukowe, Poznań 2016.

Kwiek M., Prywatyzacja i deprywatyzacja: od ekspansji do implozji szkolnictwa wyższego w Polsce, „Praktyka Teoretyczna” 2015, nr 3, s. 120-145.

Lipowski M., Student as consumer. Benefits of being academic city, referat zaprezentowany podczas konferencji „Human Capital without Borders Knowledge and Learning for Quality of Life”, Portorož 2014.

Munro M.,Livingston M., Student Impacts on Urban Neighbourhoods: Policy Approaches, Discourses and Dilemmas, „Urban Studies”2012, vol. 49(8), s. 1679-1694, http://doi.org/10.1177/0042098011419237.

Murzyn-Kupisz M., Szmytkowska M., Studentification in The Post-Socialist Context: The Case of Cracow and The Tri-City (Gdansk, Gdynia and Sopot), „Geografie” 2015, vol. 120(2), s. $188-209$.

Nakazawa T., Expanding the scope of studentification studies, „Geography Compass” 2017, vol. 11, http://doi.org/10.1111/gec3.12300.

Nowak M., Mieszkaniec a użytkownik zewnętrzny - perspektywa krytyczna, ,Rozwój Regionalny i Polityka Regionalna” 2015, nr 31, s. 7-16.

Rugg J., Rhodes D., Jones A., Studying a Niche Market: UK Students and the Private Rented Sector, „Housing Studies” 2002, vol. 17(2), s. 289-303, http://doi.org/10.1080/02673030220123234.

Smith D.P, ,,Studentification ication”: the gentrification factory?, [w:] R. Atkinson, G. Bridge (eds.), Gentrification in a global context: the new urban colonialism, Routledge, London 2005.

Sokołowicz M.E., Boryczka E.M., Tożsamość i wizerunek dużego miasta wobec międzynarodowej mobilności osób dobrze wykształconych. Przykład Łodzi w oczach studentów łódzkich uczelni, „Zeszyty Naukowe Politechniki Poznańskiej. Architektura i Urbanistyka” 2011, nr 24, s. 1-12. 


\section{Streszczenie}

Zakwaterowanie studenckie zyskało w ostatnich latach szczególną uwagę badaczy. Doświadczenia brytyjskie wskazują, że rynki zakwaterowania prywatnego adresowanego do studentów zaczęły dynamicznie rozwijać się w tamtejszych miastach akademickich wskutek umasowienia szkolnictwa wyższego. Celem artykułu jest omówienie tych doświadczeń w kontekście polskim. Przedstawiono w nim zmianę populacji studentów w 18 dużych ośrodkach akademickich kraju oraz ich liczby i odsetka korzystającego z zakwaterowania oferowanego przez uczelnie. Wskazano, że między rokiem 2004 i 2014 populacja studentów uległa zwiększeniu w 10 spośród analizowanych ośrodków, a liczba i odsetek studentów zakwaterowanych w uczelnianych akademikach zmalały w 17 ośrodkach. W omawianej dekadzie polskie miasta akademickie mogły zatem doświadczyć wzrostu liczby studentów poszukujących zakwaterowania na rynku prywatnym.

Słowa kluczowe: zakwaterowanie studenckie, miasta akademickie, studenci, domy studenckie, studentyfikacja, PBSA

Klasyfikacja JEL: R31 